Diplomacy on Ice 
This page intentionally left blank 


\title{
DIPLOMACY $\mathrm{ON}$ ICE
}

Energy and the Environment in the Arctic and Antarctic

\author{
EDITED BY \\ Rebecca Pincus \\ Saleem H. Ali \\ Foreword by James Gustave Speth
}

\author{
Yale \\ UNIVERSITY PRESS
}

New Haven and London 
Published with assistance from the Sustainable Minerals Institute, University of Queensland, Australia, and from the foundation established in memory of Amasa Stone Mather of the Class of ig07, Yale College.

\section{Copyright (C) 2015 by Yale University.}

\section{All rights reserved.}

This book may not be reproduced, in whole or in part, including illustrations, in any form (beyond that copying permitted by Sections I07 and Io8 of the U.S. Copyright Law and except by reviewers for the public press), without written permission from the publishers.

Yale University Press books may be purchased in quantity for educational, business, or promotional use. For information, please e-mail sales.press@ yale.edu (U.S. office) or sales@yaleup.co.uk (U.K. office).

Figures prepared by Bill Nelson, except for figure I2.I.

Designed by James J. Johnson.

Set in Scala types by Newgen North America.

Printed in the United States of America.

\section{Library of Congress Cataloging-in-Publication Data}

Diplomacy on ice : energy and the environment in the Arctic and Antarctic / edited by Rebecca H. Pincus, Saleem H. Ali ; foreword by James Gustave Speth.

pages $\mathrm{cm}$

Includes bibliographical references and index. ISBN 978-0-300-20516-9 (hardback)

I. Geopolitics-Polar regions. 2. Polar regions-International status.

3. Energy development-Environmental aspects-Polar regions. I. Pincus,

Rebecca H., editor of compilation. II. Ali, Saleem H. (Saleem Hassan), I973- editor of compilation.

$$
\begin{gathered}
\text { G593.D57 20I5 } \\
\text { 9I9.8-dc23 } \\
\text { 20I40I429I }
\end{gathered}
$$

A catalogue record for this book is available from the British Library.

This paper meets the requirements of ANSI/NISO Z39.48-1992 (Permanence of Paper). 
This volume is dedicated to all those scholars who commit to work in extreme environments and have a planetary vision of diplomacy. 
Why then do we feel this strange attraction for these polar regions, a feeling so powerful and lasting, that when we return home we forget the mental and physical hardships, and want nothing more than to return to them? Why are we so susceptible to the charm of these landscapes when they are so empty and terrifying?

—JEAN-BAPTISTE CHARCOT 